\title{
Nursing care in terminality: compliance with principles of bioethics
}

\author{
O cuidar de enfermagem na terminalidade: \\ observância dos princípios da bioética \\ Atención de enfermería en la terminalidad: \\ cumplimiento de los principios de bioética
}

\author{
Zirleide Carlos Felix ${ }^{\mathrm{a}}$ \\ Patrícia Serpa de Souza Batista ${ }^{b}$ \\ Solange Fátima Geraldo da Costac \\ Maria Emília Limeira Lopes ${ }^{\mathrm{d}}$ \\ Regina Célia de Oliveira \\ Fátima Maria da Silva Abrãof
}

D0l: $\quad$ http://dx.doi.org/10.1590/19831447.2014.03.46405

\footnotetext{
a Nurse. Master's in Nursing from the Federal University of Paraiba (UFPB). Professor at the Institute of Higher Education of Paraíba (IESP). João Pessoa, PB, Brazil.

${ }^{b}$ Nurse. PhD in Education from UFPB. Professor of Undergraduate course in Nursing - UFPB. João Pessoa, PB, Brazil.

c Nurse. PhD in Nursing from the University of São Paulo/School of Nursing, Ribeirão Preto. Professor at the Nursing Graduate Program UFPB. João Pessoa, PB, Brazil.

N Nurse. PhD in Education from the Federal University of Rio Grande do Norte (UFRN). Professor at the Nursing Undergraduate course - UFPB. João Pessoa, PB, Brazil.

e Nurse. PhD in Nursing from the University of São Paulo/School of Nursing, Ribeirão Preto (USP/EERP). Adjunct Professor, School of Nursing Our Lady of Grace, University of Pernambuco (FENSG/UPE), Recife, PE, Brazil.

${ }^{f}$ Nurse. PhD in Nursing from the USP/EERP. Adjunct Professor of FENSG/UPE. Recife, PE, Brazil.
}

\section{ABSTRACT}

The aim of the study was to investigate the principles of bioethics reported by nurses when caring for terminally ill patients. Exploratory research with qualitative approach, developed with fifteen nurses from an intensive care unit of a university hospital, in northeastern Brazil. Data collection was conducted between March and July 2013, through a form. Data were analyzed using the technique of content analysis, emerging the following thematic category: respect to the principles of autonomy, beneficence, non-maleficence and justice to take care of the terminally ill patients. The participating nurses valued these principles when caring for terminally ill patients, which reflect the ethical commitment of these professionals in the practice of nursing care. It is noteworthy that bioethical principles should guide the nursing care of human beings throughout their life cycle.

Descriptors: Nursing care. Terminal care. Terminally ill. Bioethics.

\section{RESUMO}

Objetivou-se investigar a observância dos princípios da bioética por enfermeiros ao cuidar de pacientes na terminalidade. Pesquisa exploratória, de natureza qualitativa, desenvolvida na Unidade de Terapia Intensiva de um Hospital Universitário, do nordeste do Brasil, com quinze enfermeiros. A coleta de dados foi realizada entre março e julho de 2013, por meio de um formulário. Os dados foram analisados mediante a técnica de análise de conteúdo, emergindo a seguinte categoria temática: respeito aos princípios da autonomia, beneficência, não maleficência e justiça ao cuidar do paciente na terminalidade. Os enfermeiros participantes do estudo valorizaram tais princípios ao cuidar de pacientes em fase terminal, o que reflete o compromisso ético desses profissionais na prática do cuidar em enfermagem. Ressalte-se que os princípios da bioética devem nortear a assistência de enfermagem ao ser humano em todo o seu ciclo vital.

Descritores: Cuidados de enfermagem. Assistência terminal. Doente terminal. Bioética.

\section{RESUMEN}

Tuvo como objetivo investigar el cumplimiento de los principios de la bioética por las enfermeras en el cuidado de pacientes con enfermedades terminales. Investigación exploratoria, de naturaleza cualitativa, desarrollado con quince enfermeras en la unidad de cuidados intensivos de un hospital universitario, en el noreste de Brasil. La recolección de datos se llevó a cabo entre marzo y julio de 2013, a través de un formulario. Los datos fueron analizados mediante la técnica de análisis de contenido, surgiendo las siguientes categorías temáticas: respetar los principios de autonomía, beneficencia, no maleficencia y justicia para cuidar al enfermo terminal. Las enfermeras participantes del estudio valoran estos principios en el cuidado de pacientes con enfermedades terminales, lo que refleja el compromiso ético de estos profesionales en la práctica de los cuidados de enfermería. Es de destacar que los principios bioéticos deben orientar la atención de enfermería de los seres humanos a lo largo de su ciclo de vida. Descriptores: Atención de enfermería. Cuidado terminal. Enfermo terminal. Bioética. 


\section{口INTRODUCTION}

Health care relates to the assistance of individuals, family and community, seeking to promote health, prevent disease and assist humans in situations of disease, based on humanistic values and scientific knowledge ${ }^{(1)}$. Specifically, in the field of nursing, care is not restricted to technical procedures, but also involves human subjectivity. Technological changes occurred in health care have required the professional to acquire new scientific knowledge and greater responsibilities to care practice, especially in relation to the terminally ill patients ${ }^{(2-3)}$.

A terminally ill patient is understood as someone who is heading to his/her death, from the diagnosis and the lack of positive response to treatment ${ }^{(4)}$. Their bodily functions no longer respond well to therapy performed, and he/she inevitably come near the possibility of dying, requiring professionals who follow this patient, a humanized care based on ethical principles.

Therefore, in patient care in face of terminal illness, it is essential to direct the attention and care to the needs and limitations of this patient, adopting an assistential care that considers them holistically, ie in their physical, emotional and spiritual dimensions and contemplate his/her singularity ${ }^{(5)}$. Accordingly, nursing professionals, especially nurses, they must promote care grounded in the holistic and humane vision, promoting strategies that encourage respect, dignity and the alleviation of suffering ${ }^{(6)}$, as well as reflecting on the value of bioethics in the scope of care.

Bioethics and its principles appear to guide human behavior from decisions towards moral conflicts before caring, contributing to a service founded on respect and human dignity. The principles of bioethics are: autonomy, beneficence, non-maleficence and justice ${ }^{(7)}$.

Autonomy refers to the ability of a person to decide, according to their values, about what she or he thinks is best for her or him. Beneficence means promoting well-being for the patient, while in non-maleficence, the health professional has a duty to do no harm and/or damage to the patient. The principle of justice refers to equal treatment, giving each person what is deserved, according to her or his needs ${ }^{(8-9)}$. These principles serve as input for the shift in thinking and actions related to the care, leading to a reflection for the achievement of a holistic and humane practice ${ }^{(9)}$.

In nurses' healthcare practice, they deal with patients who are terminally ill, it is observed that many of these professionals provide humanized care based on the principles of bioethics, while others do not offer a guided care in ethical actions that respect and value human existence.
Given the need for reflection on the care of terminally ill patients, this research is based on the following research question: Do nurses follow the observance of the principles of bioethics in the care of terminally ill patients? Based on these considerations, this study aims to investigate compliance with the principles of bioethics by nurses when caring for terminally ill patients.

\section{METHODOLOGY}

This is an exploratory study of qualitative approach. The research was conducted in the intensive care unit of a university hospital in northeastern Brazil.

This university hospital is characterized as a referral hospital in the state of Paraíba, which serves the city of João Pessoa and surroundings, offering outpatient, clinical, surgical and intensive care services to the population that seeks care. This institution provides the following Clinics: Medical, Pediatric, Surgical, Infectious Diseases, Obstetrics, Intensive Care Unit. The Intensive Care Unit was chosen to undertake this research, because its location is frequently where critically ill patients are admitted and who often progress to a terminality state, requiring specific care for the patient and also for their family members and relatives.

In this hospital ward, a multidisciplinary team, according to the needs and limitations they experience, cares for patients. Professionals who work there, especially the nurses, also seek to behold them, not only in their biological dimension, but in their emotional and social dimensions, respecting their values and spiritual beliefs. Furthermore, they seek assistance for the family of the patient, which is usually fragile and fearful given the terminality experienced by their loved one.

It is noteworthy that some professionals in this institution are part of the Center for Studies and Research in Bioethics, which work in the research area on palliative care, which includes studies targeted to patients without therapeutic possibilities of cure and in life terminal illness. In addition, the Hospital has a project to implement a Hospitalization Unit for Palliative Care, for the promotion of this specialized service.

Study participants were fifteen clinical nurses who deal directly with patients, who are terminally ill. They were selected according to the following criteria: be in professional practice during data collection; have at least one year of professional experience in the institution selected for the study; have an interest and willingness to participate in this research, confirming the participation by signing the Consent Form (CF).

Data collection took place from March to July 2013, being initiated after submission and approval of the re- 
search project by the Committee of Ethics in Research of the aforementioned hospital with CAAE record No. 13289213.1.0000.5183. It is worth mentioning that ethical recommendations were provided in Resolution No. 466/12 complied with the National Health Council, which regulates research on human beings in the country ${ }^{(10)}$.

For the acquisition of empirical data, we used a form containing a pertinent research question for the proposed objective: How do you use the principles of bioethics to assist the patient who is terminally ill? It is worth mentioning that this study is part of bigger research, taken from a dissertation titled: The experience of nurses in caring for patients who are terminally ill: A bioethical approach presented to the Nursing Graduate Program of the Federal University of Paraíba ${ }^{(11)}$.

The empirical data was analyzed by the technique of content analysis proposed by Bardin ${ }^{(12)}$, understood as a set of techniques for communication analysis, which aims to get systematic processes and objectives defining the content of the messages and indicators that allow the induction of information on the categories of production of messages. For the operationalization of the technique the following steps were taken: Pre-analysis, in which the researcher conducted a brief reading of the data obtained; Exploration of data phase: in which we highlighted relevant points of each question and then grouped and organized them into thematic categories; and last phase of Interpretation of Results, in which the empirical data are analyzed according to the themes revealed, supported by the relevant literature on the topic studied ${ }^{(12)}$. From the analysis, the following category emerged: Respect for the principles of autonomy, beneficence, non-maleficence and justice to take care of the terminally ill patients.

\section{RESULTS AND DISCUSSION}

This study was contemplated with a thematic category whose content reveals how nurses use the principles of bioethics in the care of terminally ill patients.

\section{Respect for the principles of autonomy, beneficence, non-maleficence and justice to take care of terminally ill patients}

Nurse participants in the study revealed the respect for the principles of bioethics in front of patients in a terminal process, ensuring, above all, an assistance of care that is based on human needs, since such principles arise as a guiding framework to base ethical decisions on their care practice.
As regards to the principle of autonomy, this guarantees patients the right to decide about his/her life and his/ her acts. This principle is considered substantial in relation to the care of terminally ill patients, as explained in the statements of some nurses who participated in the study.

To exercise the autonomy of the patient, when possible, I ask what are their wishes and fears [...]. (E1)

\section{[...] To preserve the autonomy of the patient, I allow him or} her to do his or her choices. (E11)

Respecting the patient's opinion, but not leaving aside my guidance on the risks that can cause the terminally ill patient. (E14)

I try to respect the patient's opinion, because I believe it is essential to their dignity. (E15)

These statements show the ethical commitment of these nurses in value the practice of caring for patients in terminality of life, when they express the importance of allowing the choices of patients to be considered during the decision making concerning themselves. The statements also show the search of these professionals to respect the decisions of patients, so that human dignity prevails. This denotes recognition of the terminal patient as a citizen who have rights that must be respected, even in the face of his or her finitude.

Study ${ }^{(13)}$ on bioethics and human finitude shows that professionals must understand that it is the patient's right, provided they are fully conscious, knowing and deciding about him or herself, giving precedence to their autonomy, even when the end of life is close. Moreover, it is worth mentioning that the family plays an important role in making decisions on the patient's terminal illness, requiring guidance from these professionals, to help in understanding this process. Some nurses were concerned with this attitude, as shown by the following excerpts from the statements below:

I try to inform the patient and family the reality of the treatment and I try not to hide anything. (E10)

I clarify the family about the importance of treatment and explain all treatment possibilities [...] for the patient. (E6)

These excerpts demonstrate the importance given by nurses to communication between staff and family in a terminality process. This action strengthens the bond and 
reveals an ethical attitude of respect for the dignity of the patient and his or her family, given human finitude.

Regarding the principle of beneficence, statements of some nurses in the study expressed the importance of a guided assistance in order to promote well-being for the patient out of therapeutic possibilities of healing and face of terminal illness. The excerpts of the statements below are illustrating this concern:

Promote the well-being to the patient by maintaining a healthy skin, nutritional care and hydration of the skin, preventing pressure ulcers... [...]. (E1)

Promoting actions that ensure benefits to the patient as hygiene and adequate nutrition, pain control using analgesics, among others. (E2)

Promoting comfort and well-being. (E5)

Prioritizing [...] decisions that may benefit the patient as a [...] person. (E13)

\section{[...] seeking symptom relief, comfort of the soul. (E14)}

[...] I try to help and do good, providing necessary assistance, trying to minimize their pain through medications for analgesia. (E15)

These statements ensure how much the appreciation of the principle of beneficence on the care of the terminally ill patients is needed. The statements show the need to promote the comfort and well-being of the terminally ill patient, ensuring basic care involving the maintenance of hygiene, nutrition, relief of physical and spiritual pain, from actions that seek to benefit them.

It is worth noting that the mentioned principle concerns the act of professionals involved in care, ensuring the recognition of the moral and ethical duty to act in the benefit of others ${ }^{(14)}$. Thus, whenever the professional is providing treatment to a person weakened by disease, she or he should recognize the patient's dignity, respecting it, appreciating it, and especially considering him or her in their comprehensiveness, promoting techniques which provide recognition of their physical, psychological or social needs ${ }^{(9)}$. Thus, the nurse is acting in order to consider the bioethical principle of beneficence.

With regard to the principle of non-maleficence, a study ${ }^{(8)}$ suggests that the health professional has a duty to do no harm and/or damage to his or her patient. Importantly, the non-maleficence is based on the minimization of risks that affect the quality of life of patients ${ }^{(15)}$. Statements of some participants of the study revealed concern to assist patients in the face of terminal illness, as shown by the following excerpts:

All procedures should be performed to patients without causing them any harm. (E3)

Promoting the well-being without causing damage [...]. (E10)

\section{[...] I don't allow unnecessary invasive procedures. (E11)}

[...] I do not adopt behaviors that promote suffering, affecting human dignity. (E14)

[...] I avoid procedures or situations, which might lead to some kind of risk. (E15)

The statements show that these professionals recognize the importance of foster care to rid patients of damage and/or foreseeable risks, and show themselves aware that they should refrain from procedures that may compromise the well-being of terminally ill patients.

It is worth mentioning that nursing professionals, when assisting the patient who is facing his/her finiteness, should avoid behaviors that favor human suffering, protecting him/her from actions that may jeopardize the quality of life of this patient and affect mainly their dignity; as mentioned in the nurse statements of the study.

Study emphasizes that health professionals should understand that given the care, even if his/her attitude does not benefit the patient, their intervention is ethically positive when they do not cause any damage. However, if it occurs omission, this could trigger damage and/or risks on their care practice ${ }^{(16)}$.

In terms of this principle, so that foreseeable harm to patients can be avoided, especially those who experience the process of terminal illness, it is necessary to get the balance between benefits and risks. In other words, one should assess to what extent endangering the quality of life of the patient is valid to achieve benefit ${ }^{(17)}$.

In this line of thought, a research ${ }^{(18)}$ suggests that the principles of beneficence and non-maleficence can be analyzed together, since the non-maleficence not only prevents damage to the patient, but rather seek to promote the well-being. Based on this understanding, one realizes that the principles of beneficence and non-maleficence are inherent to each other, since when promoting the well-being, professionals will consequently also promote 
actions aimed at preventing the risk and harm to patients without therapeutic possibilities of cure.

However, caring for people at the end of life in an Intensive Care Unit is a complex situation. It is appropriate to recognize that these patients are experiencing a situation of suffering and physical limitation due to the severity of the clinical status, being frequently exposed to therapeutic procedures aimed at prolonging life. Thus, nurses participating in the study said that in their practice, they also faced dilemmas, as the following statements refer:

Noticing that the patient no longer has a favorable prognosis and persists in treatments to prolong the natural process of death. (E1)

Use of procedures and drugs that prolong life and suffering of a terminally ill patient. (E4)

Performing procedures that do not interfere with the outcome thereof; causing unnecessary pain. (E5)

These discourses addresses a common situation in Intensive Care Units which is the usage of specific therapy directed at prolonging life, which sometimes makes the process of dying more excruciating and painful for the patient, who is already in terminal illness of life, that is, with no therapeutic possibilities of cure, the prognosis is unfavorable, in which death is inevitable.

The availability of technology and medicine in the ICU leads to therapeutic obstinacy that denies death, with the submission of the patient to a longer process of life that characterizes dysthanasia, interfering with the welfare and dignity of the patient in their terminal illness ${ }^{(19)}$.

Study ${ }^{(19)}$ addresses the complexity of the topic dysthanasia, highlighting important aspects to be reflected, as the influence of religious, ethical and legal aspects used for the practice of professionals in the treatment of patients without therapeutic possibilities of cure, bringing the need to expand communication between professionals, the patient (when possible) and the family itself. With regard to the treatment, to which this patient had preserved their dignity and autonomy throughout the therapeutic process involving terminal illness of life. Thus, they shall be preserved not only the bioethical principles of beneficence and non-maleficence, but also the autonomy and justice to these human beings who deserve to experience this terminally ill phase of life with dignity in a humane and ethical way.

As regards the principle of justice, before ethical situations involving terminally ill patients, some nurse participants in the study demonstrated, in their statements, that every patient should be assisted in an equalitarian way, showing fairness and justice as a fundamental factor in the care process:

I try to treat all patients equally, so there is no injustice in the treatment, care, in ducts. (E1)

I use of justice when treating all patients equally, without favoritism, impartially. (E4)

I provide care regardless of race, color, religion, creed. (E7)

Technological advances (for example) should benefit all, not the groups individually. (E8)

I seek to provide equity to all patients [...]. (E13)

I seek to treat patients fairly and equitably, hoping to protect the integrity and life, trying to ensure equal rights for all, without prejudice. (E15)

The interviews show the recognition by these nurses about the rights of each patient, from respect for their differences and needs to receive fair and equal treatment, regardless of color, race or religion. It is observed that, for these professionals, the principle of justice is put in place from the moment that actions that address the needs of patients in their particularities are provided. This is significant in the statements of the nurses, when they claim that benefit all patients equitably receive in their care practice.

In this perspective, acting with justice presupposes an equitable care to all patients, considering their clinical and social conditions. This implies that, to be fair, one must understand the needs of each patient and direct care according to those needs ${ }^{(18)}$.

In order for an equitable assistance occurs, it is necessary that health professionals, especially nurses, seek to recognize other's right, so that they may offer to the terminally ill patient all possible care. Therefore, nurses who took part in the study seek to promote a service in its completeness in order to ensure equitable care to all patients who experience the process of human terminally care.

In this sense, we need to respect with justice and equity the rights of everyone, because decision making should not take into account only one part, whether the professional or the patient, would be unethical and harmful(9).

Therefore, the value of bioethical principles is undeniable to guide professionals to decide and act properly, as these principles are intended to assist the individual in their 
completeness, that is, in their rational, psychological and spiritual dimension ${ }^{(4)}$.

Given the above, one realizes that the issues related to end of life is guided from the principles of bioethics, since such principles serve to drive the strategies aimed at humane actions in the human terminally process.

\section{GINAL CONSIDERATIONS}

The present study highlights the reflection on the use of the principles of bioethics in the care in the process of terminally ill patients. Through this, it was noted that nurse participants in this study recognize the importance of using the principles of autonomy, beneficence, non-maleficence and justice in the practices involving humans who are terminally ill. Compliance with these principles help to guide ethical actions, and to support humane actions in the death and dying process of terminally ill patients, contributing to the promotion of care and ensuring respect for human dignity.

It should be noted that the principles of bioethics are of fundamental importance to guide the nursing care of human beings throughout their life cycle and not just to promote care for the terminally ill person. Based on the foregoing, it is expected that this research will support new research under the nursing care for children, adults, elderly, and in situations that foster ethical dilemmas, such as issues relating to euthanasia, dysthanasia, research involving vulnerable groups, among others.

It is noteworthy that the study has limitations, since the number of participants does not allow generalizations of the investigated phenomenon, and it is a specific group of patients.

\section{口EFERENCES}

1. Silva RS, Campos AER, Pereira A. Cuidando do paciente no processo de morte na unidade de terapia intensiva. Rev Esc Enferm USP. 2011;45(3):738-44.

2. Souza LF, Misko MD, Silva L, Poles K, Santos MR, Bousso RS. Morte digna da criança: percepção de enfermeiros de uma unidade de oncologia. Rev Esc Enferm USP. 2013;47(1):30-7.

\section{Author's address:}

Zirleide Carlos Felix

Rua Odiza Eliseu da Nóbrega, 29, ap. 304, Jardim Oceania

58037-145, João Pessoa, PB

E-mail: zirleidefelix@hotmail.com
3. Moraes TM. Como cuidar de um doente em fase avançada de doença. Mundo Saúde. 2009;33(2):231-8.

4. Celedón C. Sufrimiento y muerte en un paciente terminal. Rev Otorrinolaringol Cir Cabeza Cuello. 2012;72:261-6.

5. Fernandes MA, Evangelista CB, Platel ICS, Agra G, Lopes MS, Rodrigues FA. Percepção dos enfermeiros sobre o significado dos cuidados paliativos em pacientes com câncer terminal. Ciênc saúde coletiva. 2013;18(9):2589-96.

6. Mota MS, Gomes GC, Coelho MF, Lunardi Filho WD, Sousa LD. Reaçoes e sentimentos de profissionais da enfermagem frente à morte dos pacientes sob seus cuidados. Rev Gaúcha Enferm. 2011;32(1):129-35.

7. Neves NMBC, Siqueira JE. A bioética no atual código de ética médica. Rev Bioética. 2010;18(2):439-50.

8. Saad ERD, Lima AP, Rodrigues C, Amorin F, Yasuda F, Santos GA et al. Bioética aplicada a pesquisa e inovação farmacêutica. Rev Pesq Inov Far. 2009; 1(1):5362.

9. Junqueira CR. Bioética: conceito, fundamentação e princípios: módulo bioética. São Paulo: UNIFESP; 2011.

10. Ministério da Saúde (BR), Conselho Nacional de Saúde. Resolução no 466, de 12 de dezembro de 2012. Diretrizes e normas requlamentadoras de pesquisa envolvendo seres humanos. Diário Oficial da União [da] República Federativa do Brasil 2013 [citado 14 de nov 2013]. Disponível em: http://conselho.saude.gov. br/ultimas_noticias/2013/06_jun_14_publicada_resolucao.html

11. Felix ZC. Vivência de enfermeiros no cuidar de pacientes na terminalidade: um enfoque bioético [dissertação]. João Pessoa: Universidade Federal da Paraíba; 2014.

12. Bardin L. Análise de conteúdo. São Paulo: Edições 70; 2011.

13. Schramm FR. Finitude e bioética do fim da vida. Rev Bras Cancerol. 2012:58(1):73-8.

14. Barbosa LNF, Fábio, GD, Marcos ABS, Josimário IS. Sobre ética e violência sexual: recortes de um caso atendido fora dos serviços especializados. Rev SBPH. 2010;13(2):299-317.

15. Teixeira RKC, Yamaki VN, Gonçalves TB, Silva JAC. Análise bioética dos anteprojetos de um CEP universitário. R Ci Med Biol. 2012;11(3):285-89.

16. Primo WQSP, Primo GRP, Cunha FMP, Garrafa V. Estudo bioético da informação do diagnóstico do HPV em uma amostra de mulheres no Distrito Federal. Rev Bioética. 2009;12(2):33-51.

17. Silva CR, Fiabani KJ, Matos JCM, Arancibia BAV. Reflexiones sobre la gestión documental frente a los principios bioéticos en la investigación científica en Brasil. Acimed. 2012;23(2):250-62.

18. Barbosa IA, Silva MJP. Cuidado humanizado de enfermagem: 0 agir com respeito em um hospital universitário. Rev Bras Enferm. 2007;60(5):546-51.

19. Santana JCB, Rigueira ACM, Dutra BS. Distanásia: reflexões sobre até quando prolongar a vida em uma unidade de terapia intensiva na percepção dos enfermeiros. Rev Bioétikos. 2011;4(4):402-11.
Rev Gaúcha Enferm. 2014 set,35(3):97-102. 